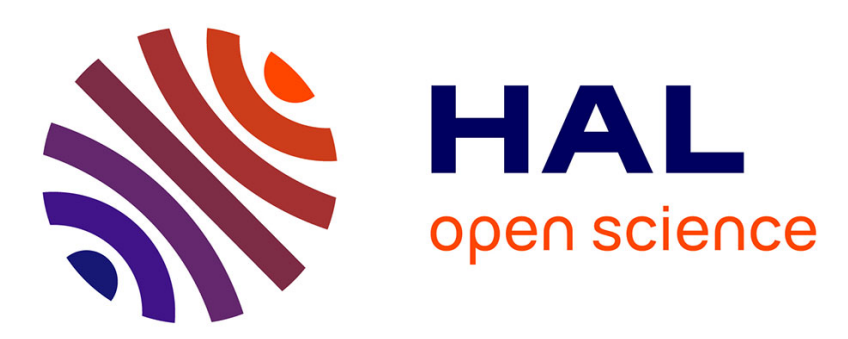

\title{
Christmas Island lagoonal lakes, models for the deposition of carbonate--evaporite--organic laminated sediments
}

Jean Trichet, Christian Défarge, J. Tribble, G.W. Tribble, F.J. Sansone

\section{To cite this version:}

Jean Trichet, Christian Défarge, J. Tribble, G.W. Tribble, F.J. Sansone. Christmas Island lagoonal lakes, models for the deposition of carbonate-evaporite-organic laminated sediments. Sedimentary Geology, 2001, 140, pp.177-189. 10.1016/S0037-0738(00)00177-9 . hal-00089124

HAL Id: hal-00089124

https://hal-insu.archives-ouvertes.fr/hal-00089124

Submitted on 10 Aug 2006

HAL is a multi-disciplinary open access archive for the deposit and dissemination of scientific research documents, whether they are published or not. The documents may come from teaching and research institutions in France or abroad, or from public or private research centers.
L'archive ouverte pluridisciplinaire HAL, est destinée au dépôt et à la diffusion de documents scientifiques de niveau recherche, publiés ou non, émanant des établissements d'enseignement et de recherche français ou étrangers, des laboratoires publics ou privés. 


\title{
Christmas Island lagoonal lakes, models for the deposition of carbonate-evaporite-organic laminated sediments
}

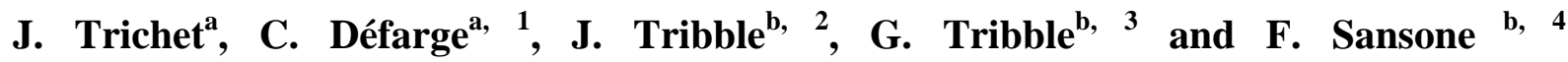 \\ ${ }^{\text {a }}$ Laboratoire de Géologie de la Matière Organique, Université d'Orléans, U.M.R. 6531 du \\ CNRS, BP 6759, F-45067 Orléans Cedex 2, France \\ ${ }^{\mathrm{b}}$ Oceanography Department, University of Hawaii, 1000 Pope Road, Honolulu, HI 96822 , \\ USA
}

\section{Abstract}

The atoll of Christmas Island (now known as Kiritimati) in the Kiribati Republic (Central Pacific) lies at about $2^{\circ} \mathrm{N}$ in the intertropical convergence zone. Much of the surface area of the atoll (ca. $360 \mathrm{~km}^{2}$ ) is occupied by numerous lakes in which carbonate, evaporite (calcium sulfate, halite) and organic layers are deposited. Observations suggest that deposition of these different laminae is controlled by climatic and biologic factors. It is thought that periodic climatic variations, such as El Niño-Southern Oscillations (ENSO) events which bring heavy rainfall to the atoll, result in the succession of the precipitation of carbonate minerals (during periods after dilution of hypersaline waters by heavy rains), followed by evaporitic minerals (carbonate, calcium sulfate, halite) when salinity increases through evaporation. Thick (up to $5 \mathrm{~cm}$ ) microbial (essentially cyanobacterial) mats develop continuously on the lake bottom surfaces providing the sediment with an important (total organic carbon 2-5\%) organic contribution in the form of an internal, geometrically structured, network in which the authigenic minerals precipitate. The high bioproductivity of these microbial populations is reflected in low $\delta^{13} \mathrm{C}$ values of sedimentary organic carbon $(-14$ to $-17 \%)$, interpreted as being the result of high atmospheric $\mathrm{CO}_{2}$ demand (Geochim. Cosmochim. Acta, 56 (1992) 335). The well-laminated organic layers present in the sediment profile result from the death and burial of microbial populations at the time of severe climatic events (storms, heavy rainfall).

These lagoonal lakes provide a model for the deposition of carbonate and organic matter in an evaporitic environment. The high ratio of deposited carbonate vs. sulfate+chloride, when compared to low ratio in evaporitic salinas, results from both a lack of limitation of calcium, magnesium and carbonate ions (in a carbonate reef environment) and active processes of high-Mg calcite precipitation (organomineralization).

Author Keywords: Carbonate-evaporite-organic laminated sediments; Lagoonal lakes; Climatic control of sedimentation; Organomineralization; Christmas Island atoll; Kiritimati 


\section{Introduction}

Laminated series displaying sequential alternations of evaporitic (anhydrite, gypsum, halite) and carbonate (calcite, dolomite) layers are encountered in numerous sedimentary basins worldwide. Two main types of environment are considered for the deposition of those laminated series: (1) standing, possibly deep (Schmalz, 1969), bodies of water, and (2) shallow water, in supratidal flats or desert environments. These two types of environment are not mutually exclusive in an evaporitic/carbonate series; strata deposited in shallow water may overlie those deposited from deeper standing-water bodies at the end of an evaporative drawdown period ( Maiklem, 1971). Shallow water evaporitic deposits can clearly form without any temporal, or spatial association with deep deposited series: for example in salt ponds, evaporative salinas or salt works. In such deposits the relative amount of deposited carbonate versus sulfate+chloride is low owing to the respective amount of these species precipitated from sea water (carbonate/sulfate+chloride, 0.1/27.109, w/w). In contrast with such very shallow water evaporitic environments other basins, such as Messinian basins considered to contain deeper waters, can be the seat of evaporite-carbonate-organic matter deposition (e.g. McKenzie; Bellanca and Decima). Periodic influx of meteoric or marine waters to evaporative basins can dilute the brines to below gypsum saturation and thereby increase the ratio of carbonate to sulfate+chloride that is deposited. The somewhat shallow water environment of deposition in some of the Messinian deposits is supported by the presence of organic-rich layers presumably derived from cyanobacterial populations that formed temporary mats on the sediment surface ( Ort and Rouchy). These sedimentary sequences, therefore, contain carbonate, evaporite, shale and organic matter layers, in various proportions.

A source of insight into the geodynamical conditions leading to such sedimentary deposits is the observation of similar Recent deposits, for which the physico-chemical and biological parameters can be observed and measured. The aim of this paper is to present a Recent environment in which the sedimentation of alternating carbonate, evaporite and organic layers is essentially controlled by climatic and biological factors. This environment is found on the large atoll of Kiritimati (formerly called Christmas Island), in the Kiribati Republic, Central Pacific. The total absence of any silicate rock in this atoll type reef environment explains the lack of any marly or clayey material within the deposits.

\section{Christmas Island atoll}

Christmas Island is located close to the Equator $\left(\sim 2^{\circ} \mathrm{N}\right)$ in the Central Pacific (Fig. 1). It is the largest of the world's atolls as defined by its land surface $\left(\mathrm{ca} .360 \mathrm{~km}^{2}\right)$. The eastern, central and north-eastern parts of the island are occupied by numerous (ca. 500) lakes (Fig. 2), separated by a few meters to tens of meters of sandy or reef rock deposits (Fig. 3). This feature in the atoll's morphology was first interpreted by Valencia (1977) as being the result of both sea level rise after the last glacial period and a northwestward tilting of the atoll. 


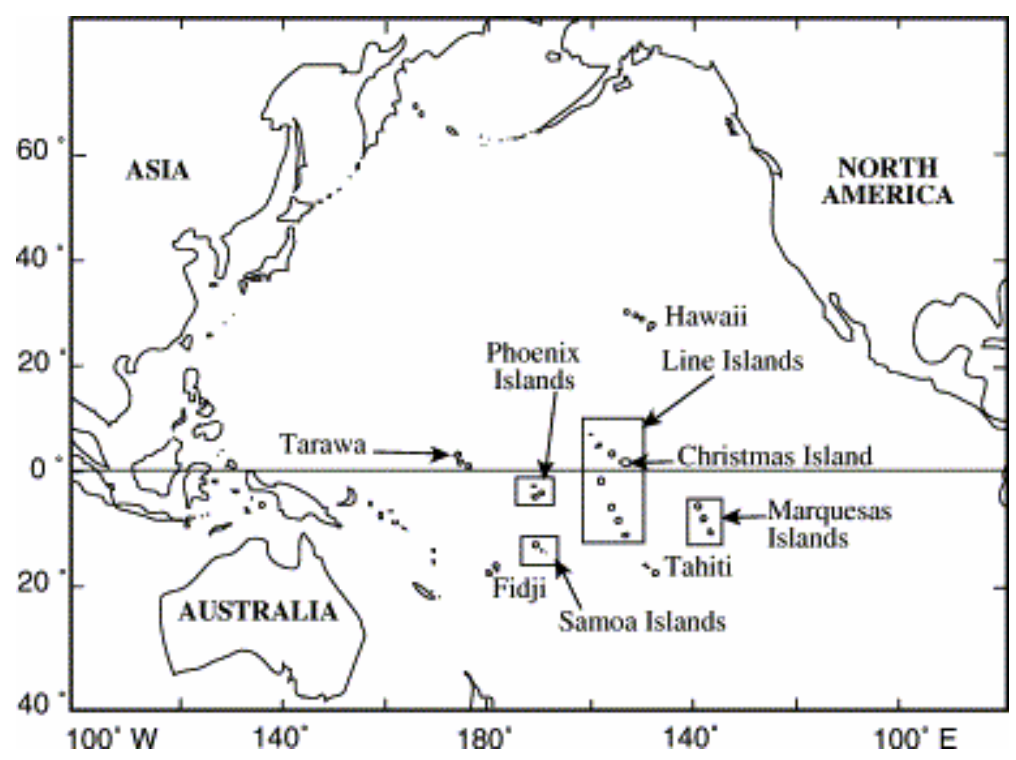

Fig. 1. Map of the Pacific Ocean showing the atoll of Christmas Island in the Line Islands archipelago.

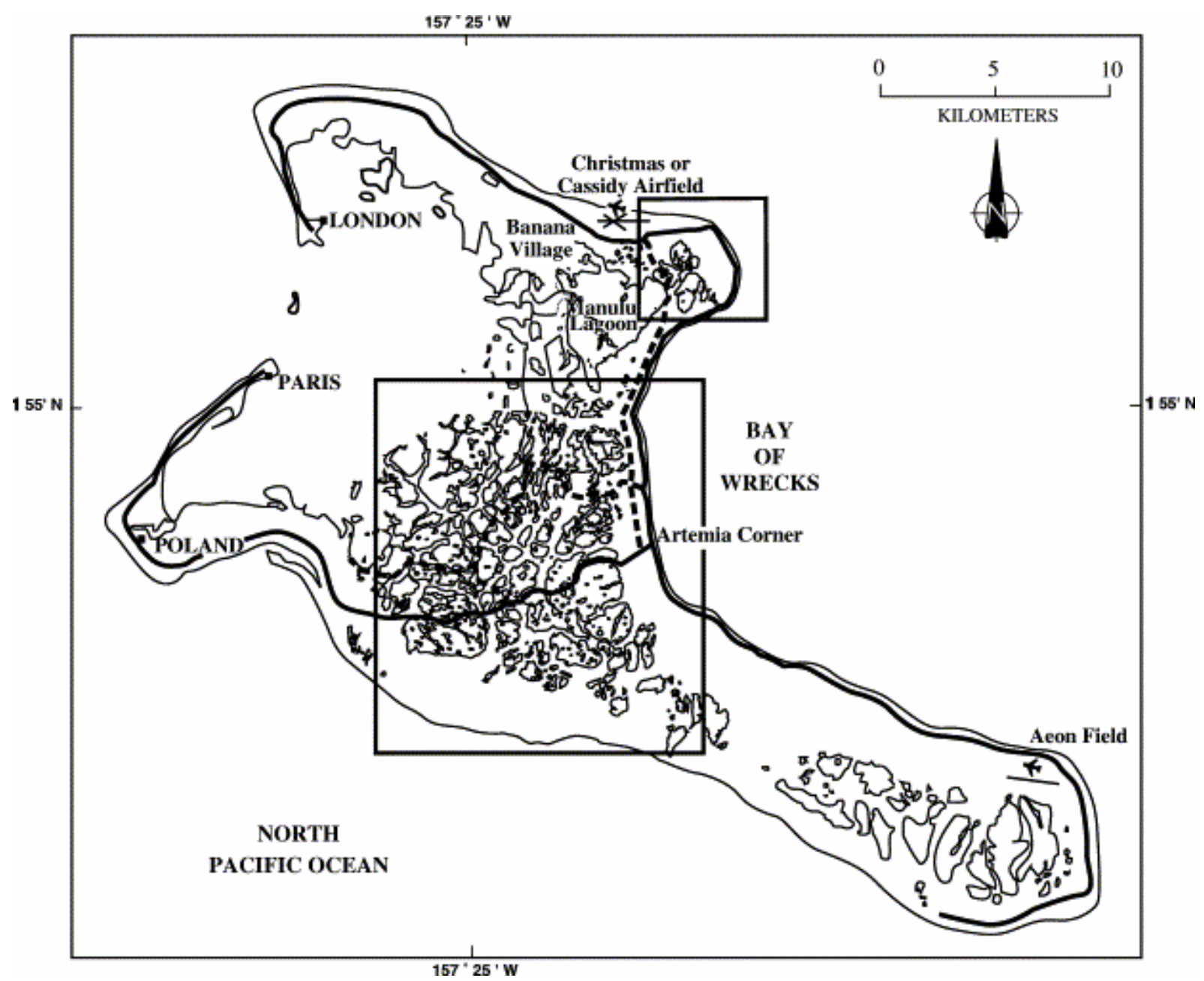

Fig. 2. Map of Christmas Island. Boxes indicate areas of lakes studied, as shown in Fig. 3a and b. 

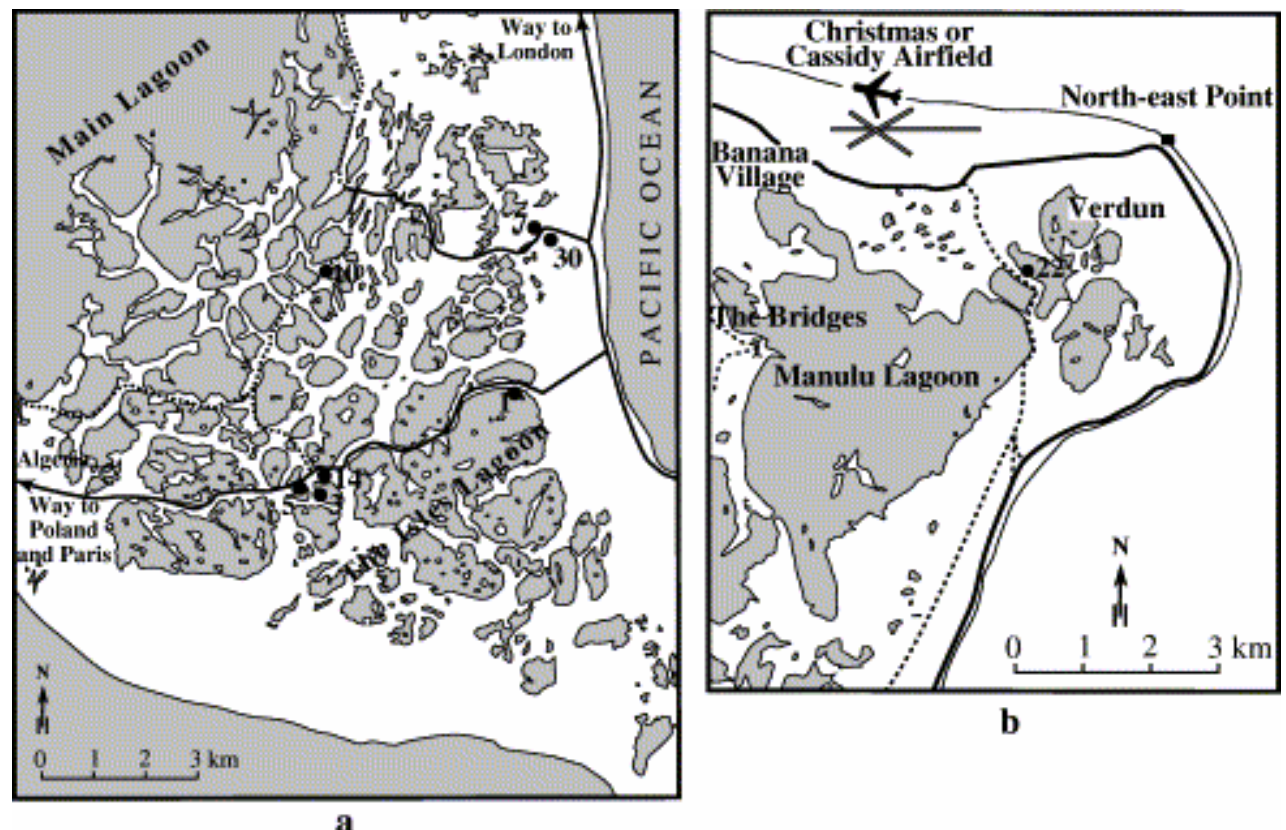

Fig. 3. Localization of lakes referred to in this paper: (a) in the eastern part of the island, and (b) in the northeastern part of the island.

The surface area of the lakes range from $16 \mathrm{~km}^{2}$ (Manulu lagoon; Fig. 2 and Fig. 3) to a few square meters for the very shallow ones (some tens of centimeters deep). They can be either isolated or interconnected, the more westerly ones being connected with the main open lagoon ( Fig. 3a). The lakes have salinities ranging from brackish (ca. 17\%o) to hypersaline ( $\geq 300 \%$; Valencia, 1977). The high salinity of some lakes is reflected in the common presence of calcium sulfate or halite deposits around the edges of the lakes.

Significant differences can be observed between close, and even adjacent, lakes: the color of the top sediment can vary from gray to red, through green, orange or pink and the water level can be significantly different (up to $1 \mathrm{~m}$ between two nearby lakes, according to Valencia, 1977). Salinity can also be significantly different between close lakes, varying for example, from $69 \%$ in lake 5 to $116 \%$ in lake 3 and 202\%o in lake 14 (Fig. 3a). Such features suggest that each lake behaves as a spatially well-defined, partly close, unit. This also suggests a very complex hydrology within the bulk lagoonal sedimentary assemblage, resulting, most probably, from a complicated association of lagoonal patch reefs and sediments that were developed and deposited, respectively, during the late Quaternary sea level rise ( Valencia, 1977). The individuality of the lakes makes their development and structure of widespread interest, given that Christmas Island provides, as a whole, a rich variety of biogeochemical conditions under similar climatic conditions.

\section{Materials and methods}

Field work was carried out in 1983, 1984, 1988 and 1990. Physico-chemical parameters were measured in the lake waters during the 1983 and 1984 visits (Schoonmaker et al., 1985) and in the interstitial solutions collected from core samples in 1990. The sediment cores were obtained using transparent, $10-\mathrm{cm}$ diameter, 100-cm long, plastic tubes. In most cases the sediment bottom was not reached, indicating sediment thicknesses over $2 \mathrm{~m}$ at a few meters 
distance from the shore line. The location and identification number of the lakes visited are shown in Fig. 3a and b.

The mineralogy of the fine fraction $(<80 \mu \mathrm{m}$, in order to eliminate larger bioclasts) was obtained by X-ray diffraction. Where $\mathrm{Mg}$ calcites were present, the percentage of $\mathrm{MgCO}_{3}$ was calculated from the position of the (104) peak (Goldsmith and Graf, 1958).

The fine structure of the sediment was observed by scanning electron microscopy, using a cryo-scanning electron microscope (Philips $525 \mathrm{M}$ equipped with an Oxford Cryotrans CT 1500 cryo-preparation system). The cryo-preparation device, which quenches the interstitial water of the samples at $-210^{\circ} \mathrm{C}$ in nitrogen slush, then sublimates the superficial ice crystals formed, enables conservation of fragile organic or organo-mineral structures by preventing distortion induced by vacuum conditions within the microscope chamber (Défarge et al., 1996).

Total organic carbon (TOC) was measured by neutralizing in $\mathrm{NaOH}$ the $\mathrm{CO}_{2}$ released by combustion of the organic residue left after treatment of the bulk sediment by $1 \mathrm{~N} \mathrm{HCl}$ (Carmhograph Wösthoff apparatus).

$\mathrm{CO}_{2}$ from both carbonate and organic carbon was prepared for mass spectrometry isotopic analysis. $\mathrm{CO}_{2}$ from carbonate was obtained from acid $\left(\mathrm{H}_{3} \mathrm{PO}_{4}\right)$ dissolution of carbonate grains. For organic carbon, the $\mathrm{CO}_{2}$ was obtained from the oxidation of the sediment organic matter, as follows. After successive $\mathrm{HCl} / \mathrm{NaOH} / \mathrm{HCl}$ treatments, the residue was subjected to combustion under vacuum, at $850^{\circ} \mathrm{C}$, for a half hour in the presence of $\mathrm{Cu}$ oxides and an $\mathrm{Ag}$ wire, in order to fix sulfur species. Water and $\mathrm{CO}_{2}$ were fixed in an acetone/dry-ice mixture and liquid $\mathrm{N}_{2}$, respectively. $\mathrm{CO}_{2}$ was then analyzed by mass spectrometry.

\section{Sedimentary facies}

\subsection{Macroscale observations}

Profiles of the uppermost sedimentary strata are shown in Fig. 4, drawn from cores taken to depths varying from 26 (in lakes 1 and 22) to $98 \mathrm{~cm}$ (in lake 7). Fig. 5b shows the facies of the topmost sedimentary layers in lake 30 and Fig. 5c-f, more detailed views of layers in lakes 22 and 30, from various depths (down to $92 \mathrm{~cm}$ in lake 30).

A notable characteristic of these deposits is the centimeter scale thickness of the top layers, which host cyanobacterial populations. This thickness can reach up to $5 \mathrm{~cm}$, as observed in lakes 4 and 22 in 1990. The thickness of the underlying strata varies from millimeters to centimeters (Fig. 5b-f).

Also of note is the alternation of three main lithological types of layers: organic-rich, carbonate-rich, and evaporitic. The so-called organic-rich layers are dark colored and finely laminated. They correspond to Present (top) or older layers which are or were composed of living microbial, essentially cyanobacterial, populations (Cohen and Ideses, 1989). As happens in other similar microbial sediments deposited in reef environments (kopara type deposits according to the name given to these deposits in the Paumotu Archipelago, Défarge et al., 1994), decay of the microbial organic matter liberates significant amounts of carotenoid (cyanobacterial and bacterial) pigments ( Trichet and Défarge, 1999), which are responsible for the reddish to brownish color of the resulting organic-rich strata. 

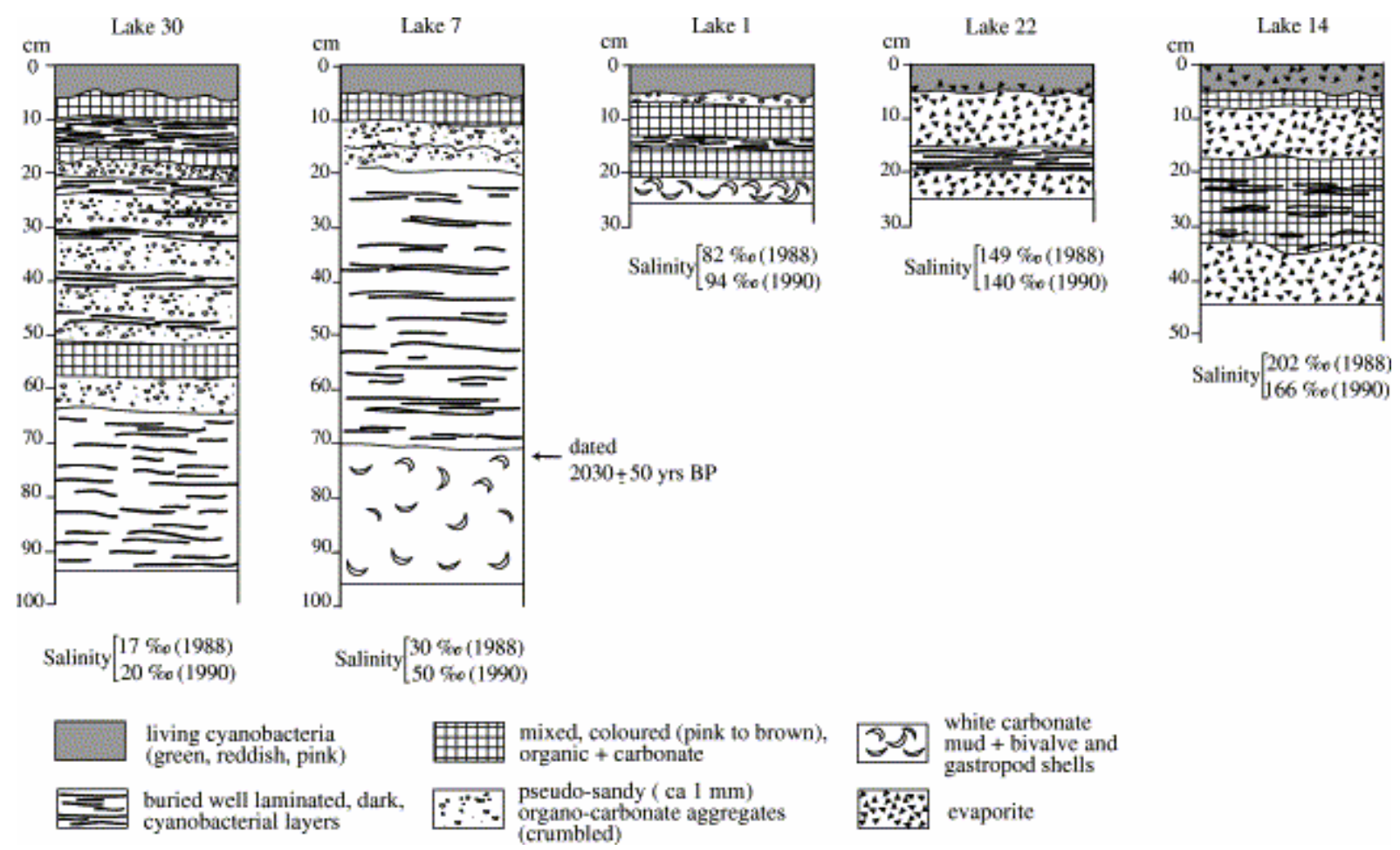

Fig. 4. Sedimentary profiles, lithology and salinity of lake water in five lakes from Christmas Island.

Carbonate-rich layers are never really white in section, but always faintly tinted (Fig. 5b-f). Although they can appear to be very fine-grained to the naked eye (for example, the white carbonated mud in the lake 7 profile; Fig. 4), they also commonly display a pseudo-sandy facies under low magnification. Examples of such a facies are given in Fig. $5 \mathrm{~d}$ and $\mathrm{f}$. The sediment is made of sub-rounded sand-sized (ca. $100 \mu \mathrm{m}-1 \mathrm{~mm}$ ) bodies whose structure can be observed under the scanning electron microscope (see following paragraph). These bodies are composed of an organo-mineral association of microbially derived organic matter and authigenic, very fine-grained $(1 \mu \mathrm{m}$ range), carbonate minerals. The presence of significant amounts of organic matter within those sand-sized bodies is suggested, in the field, by the gelatinous habit of these whitish layers. Shells or shelly fragments, generally localized in discrete levels, are also common carbonate constituents of the sediments (lake 1, Fig. 4).

Evaporite-rich layers are identified at low magnification by their light, translucent character. They contain mainly either halite (water soluble) or gypsum (less water and $\mathrm{HCl}$ soluble). Dissolution in water generally leaves a substantial residue, indicating that gypsum is dominant in most of the evaporitic layers collected in our 1990 excursion. X-ray diffraction of cores taken on earlier excursions confirms that gypsum is much more abundant than halite in most samples analyzed. No other evaporative salts were identified. Coarse grains can be seen at low magnification (Fig. 5e) and the contact between evaporitic and other, generally organicrich, layers is either abrupt or more complex ( Fig. 5e). 

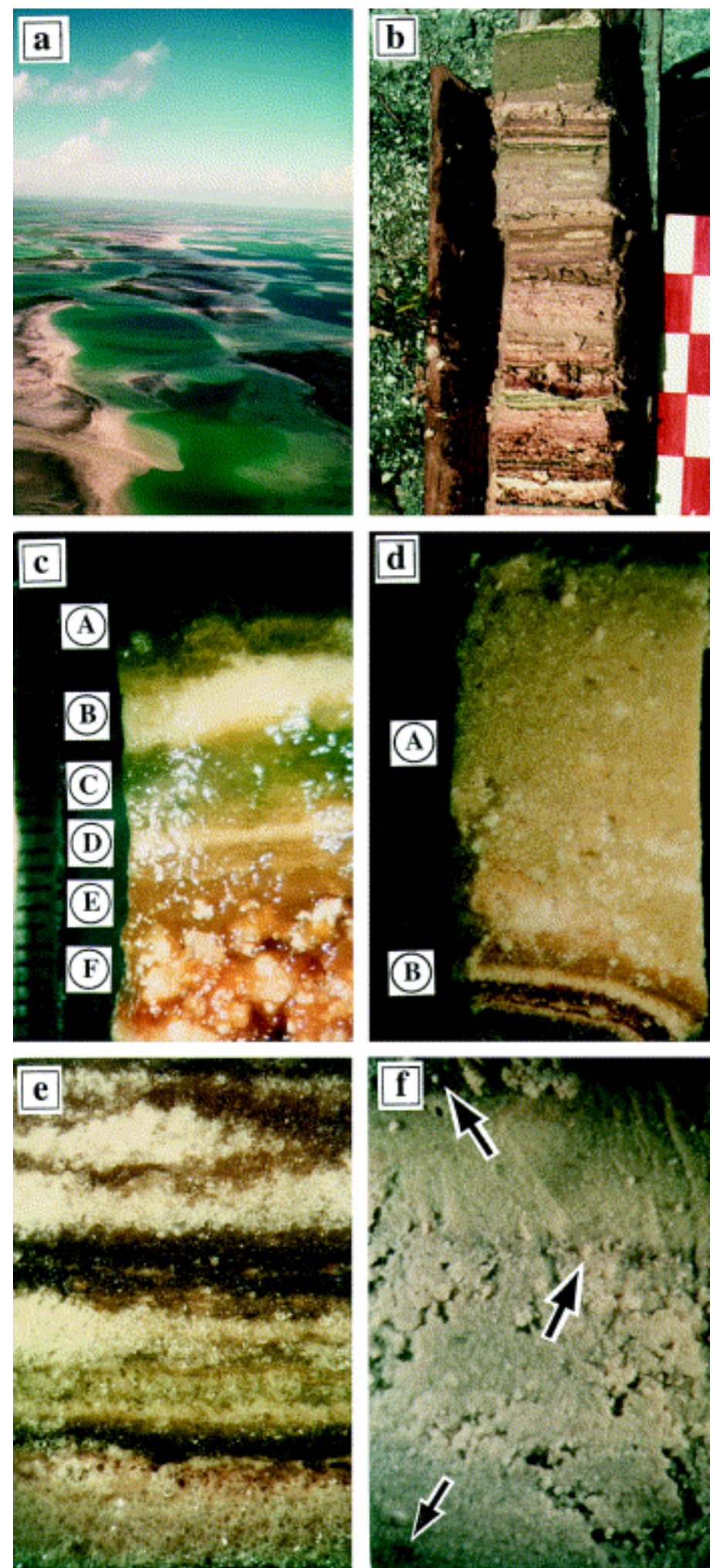

Fig. 5. Field and stereomicroscope photographs. (a) Aerial view of the lakes in the eastern part of Kiritimati Island. (b) Top of a core collected from lake 30 sediment. Scale graduation is $5 \mathrm{~cm}$. (c) Stereomicroscope view of the top of lake 22 sediment. Scale graduation is $1 \mathrm{~mm}$. A: Green to orange, superficial organic-rich layer, including $\mathrm{Ca}-\mathrm{Mg}$ carbonate and gypsum minerals. B: White mineral-rich layer composed of $\mathrm{Ca}-\mathrm{Mg}$ carbonates, gypsum, halite and organic matter. C: Green organic-rich layer similar to layer A. D: White mineral-rich layer similar to layer B. E: Red organic-rich layer including $\mathrm{Ca}-\mathrm{Mg}$ carbonate and gypsum minerals. F: Layer similar to layer E, with larger gypsum crystals. The light spots scattered on the picture correspond to water droplets which formed, soon after the sample was removed from the refrigerator. (d) Stereomicroscope view of lake 30 sediment between 8 and $11 \mathrm{~cm}$ depth, showing a gelatinous, carbonate pseudo-sandy layer (A), overlaying a stromatolitic layer (B) composed of alternating organic and $\mathrm{Ca}-\mathrm{Mg}$ carbonate-rich laminae. Each fine sand-sized 
(ca. $100 \mu \mathrm{m}$ ) grain is an organo-mineral aggregate of $\mathrm{Ca}-\mathrm{Mg}$ carbonate and organic matter. Same scale as in Fig. 5c. (e) Stereomicroscope view of lake 22 sediment between 25 and $28 \mathrm{~cm}$ below the surface, showing its stromatolitic texture formed by an alternation of dark organic-rich and white mineral-rich sub-horizontal laminae. The minerals are tiny white, $\mathrm{Ca}-\mathrm{Mg}$ carbonate grains or large translucent gypsum crystals. The vertical dimension of the image corresponds to $1.5 \mathrm{~cm}$. (f) Stereomicroscope view of lake 30 sediment between 87 and $92 \mathrm{~cm}$ below the surface. A carbonate pseudo-sandy layer is interbedded between thin dark sub-horizontal organic laminae (arrows). Sandy-sized (ca. $1 \mathrm{~mm}$ ) grains are organo-mineral aggregates with a composition similar to that described in photo (d). See the ultrastructure of such grains in Fig. 6g. Same scale as in Fig. 5c and $\mathrm{d}$.

\subsection{Scanning electron microscopy}

All layers of the deposit share a common feature (Fig. 6a-e, g and h), which is the presence of a well-structured, honeycomb-like, porous (ca. 1 to several tens of micrometers in size) organic network. This network, also present in kopara deposits, results from the reorganization of polysaccharidic and glycoproteic fibrous constituents of the microbial (essentially cyanobacterial) sheaths (Défarge et al., 1994). The physical role of this microbially derived organic matter is clearly important for the sediment, being responsible for the gelatinous habit of most layers and also for the behaviour of the sand-sized grains with respect to reworking and transport processes.

Minerals precipitate authigenically within this organic mesh, as is shown in Fig. 6b-e and $g$ (for high-Mg calcite) and in Fig. 6h (for gypsum). The mean size of carbonate aggregates is in the one to tens of micron range, each grain being micritic.

Magnesian calcite grains show a variety of morphologies, all indicative of bacterial origin (Défarge et al., 1996), as shown in Fig. 6f. Such mineralized bacteria are observed only in certain levels, in particular in the pseudo-sandy gelatinous layers. Similar occurrences are observed in kopara type deposits ( Défarge et al., 1996). 

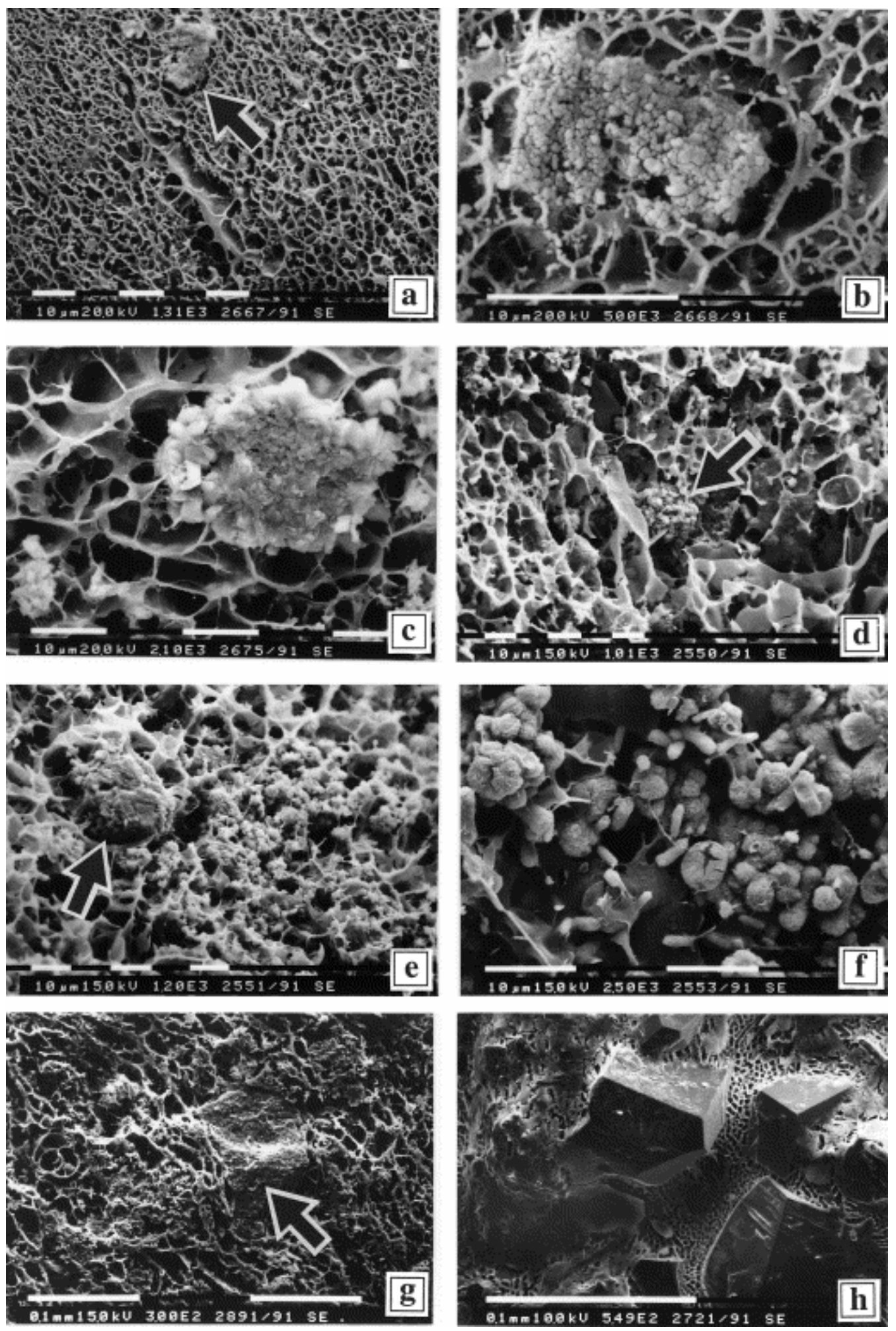

Fig. 6. Cryo-SEM micrographs of the sediments. (a-c) Lake 30, top $10 \mathrm{~cm}$ of the sediment, stromatolitic layer. (a) View of an organic lamina, showing its reticular organization. The area indicated by arrows is magnified in Fig. 6b. (b) Aggregate of magnesian calcite grains which have precipitated within the organic network. (c) View of the ultrastructure of a carbonate lamina, showing clusters of $\mathrm{Mg}$ calcite precipitates of various sizes, closely associated with organic network walls. (d-f) Lake 30, top $10 \mathrm{~cm}$ of the sediment; gelatinous, carbonate pseudosandy layer. (d) View showing the organic framework of the layer, and an Mg calcite aggregate (arrow) closely associated with organic walls. (e) Mg calcite precipitates associated with organic network walls, or, for one (arrow), likely formed within an emptied cyanobacterial filament. (f) $\mathrm{Mg}$ calcite rods, fans, dumbbells and spheroidal aggregates, all evocative of encapsulated bacteria, and an unidentified, torn, organic body. (g) Lake 
30, carbonate pseudo-sandy layer between 87 and $92 \mathrm{~cm}$ below the surface of the sediment. View showing the organic framework within the sediment, some large, most probably detrital, aragonite or calcite grains (arrow), and small-sized Mg calcite precipitates associated with the network walls (e.g. on the left of the arrowed grain). (h) Lake 22, stromatolitic layer between 25 and $28 \mathrm{~cm}$ below the surface of the sediment. View of a mineral-rich lamina, showing its organic framework (more or less distorted by sample preparation) and large gypsum crystals cutting through the organic network. Microprobe analysis of mineral components present between the gypsum crystals indicates the presence of $\mathrm{Ca}$ and $\mathrm{Mg}$.

\section{Mineralogical data}

The results of qualitative mineralogical analyses performed by X-ray diffraction in surface and core sediment samples from lakes 4 and 22 are shown in Table 1. The reported results are from the University of Hawaii and have been obtained from study of bulk sediment. The mineralogical analysis shows the presence, in variable proportions, of carbonate minerals (calcite, aragonite), calcium sulfate (gypsum, bassanite and possibly anhydrite), halite and unknown mineral(s). It is thought that the bassanite and anhydrite are possible artifacts resulting either from dehydration of gypsum or from precipitation out of remaining pore water during drying of the samples (at $60^{\circ} \mathrm{C}$ ). Anhydrite can also form naturally from gypsum dehydration under certain field temperatures $\left(\mathrm{ca} .60^{\circ} \mathrm{C}\right)$.

Table 1. Qualitative mineralogical composition of samples from lakes 14 and $22 . \mathrm{H}=$ halite, $\mathrm{G}=\mathrm{gypsum}$, $\mathrm{An}=$ anhydrite, $\mathrm{B}=$ bassanite, $\mathrm{A}=$ aragonite, $\mathrm{C}=$ calcite, $\mathrm{U}=$ unknown (peaks at 3.13,2.22, and $1.81 \AA$ ). Minerals are listed in order of decreasing abundance

\begin{tabular}{ccl}
\hline & Depth $(\mathrm{cm})$ & Mineralogy \\
\hline Lake 14 & mat & A \\
& $1.5-3$ & H, G \\
$6-8$ & G, B, An? \\
$9-11$ & G, B, A, An?, H? \\
$16-20$ & B, G, H?, A? \\
$26-28$ & G, B, H \\
$46-48$ & G, H, B, A \\
$55-56$ & G, H, B \\
& nepheloid & U, H, A \\
$0-1$ & G, B, U, A, C? \\
$1-2$ & U, G, A, B \\
$2-3$ & $3-4$ & G, U, H, A, B \\
$4-4.5$ & G, U, H, A, B \\
$4.5-6$ & G, B, A \\
$6-7$ & G, B, A \\
$7-8$ & G, B, A \\
$8-9.5$ & G, B, A \\
& & G, B, A, An?
\end{tabular}

The mineralogy of fine-grained $(<40 \mu \mathrm{m})$ carbonates in layers of lake 30 (Table 2) shows the dominance throughout the sediment of high-Mg calcite with a $\mathrm{Mg}$ content (7.3-14.7 mole\% $\mathrm{MgCO}_{3}$ ) similar to that of the precipitated $\mathrm{Mg}$ calcite from kopara type deposits $(7-19 \%$ 
$\mathrm{MgCO}_{3}$; Défarge et al., 1996). The $\mathrm{Mg}$ calcite is accompanied, below $40 \mathrm{~cm}$, by significant amounts of aragonite and, below $17 \mathrm{~cm}$ depth, by protodolomite (high-Mg calcite with 40.4$\left.43.3 \mathrm{~mole} \% \mathrm{MgCO}_{3}\right)$. Traces of another $\mathrm{Mg}$ calcite type mineral $\left(27.8 \mathrm{~mole} \% \mathrm{MgCO}_{3}\right)$ are observed in one level, quartz occurs in the bottommost part of the sediment and halite is present in some levels. Halite, however, could be an artifact from sample handling.

Table 2. Qualitative mineralogical composition of $<40 \mu \mathrm{m}$ fraction of lake 30 sediments: $(+++)$ major, $(++)$ minor, and $(+)$ traces

\begin{tabular}{|c|c|c|c|c|c|c|c|}
\hline \multirow[t]{2}{*}{ Depth $(\mathrm{cm})$} & \multicolumn{2}{|l|}{ Mg calcite } & \multicolumn{2}{|c|}{ Protodolomite } & \multirow[t]{2}{*}{ Aragonite } & \multirow[t]{2}{*}{ Halite } & \multirow[t]{2}{*}{ Other minerals (traces) } \\
\hline & Abundance & $\mathrm{MgCO}_{3}(\mathrm{~mole} \%)$ & Abundance & $\mathrm{MgCO}_{3}(\mathrm{~mole} \%)$ & & & \\
\hline $0-7$ & +++ & 12.1 & - & - & - & - & - \\
\hline $7-17$ & +++ & 14.0 & - & - & + & + & - \\
\hline $17-27$ & +++ & 14.7 & ++ & 41.3 & - & + & - \\
\hline $40-50$ & +++ & 14.3 & ++ & 40.4 & +++ & - & - \\
\hline $50-60$ & +++ & 11.7 & ++ & 43.3 & +++ & + & $\mathrm{Mg}$ calcite $27.8 \%$ mole $\mathrm{MgCO}_{3}$ \\
\hline $60-68$ & +++ & 7.9 & + & 44.4 & +++ & ++ & - \\
\hline $83-93$ & + & 7.3 & + & 42.4 & + & ++ & Quartz \\
\hline
\end{tabular}

\section{Carbon isotopic data}

Isotopic data for organic and inorganic carbon in fine-grained $(<40 \mu \mathrm{m})$ carbonate in samples from lake 30, as well as the TOC content in these fractions, are presented in Table 3. TOC varies between 2 and $5 \% . \delta^{13} \mathrm{C}$ for carbonates is slightly positive, with the exception of the top sample where it is slightly negative. $\delta^{13} \mathrm{C}$ for organic carbon is negative, with values between -14 and $-18 \%$.

Table 3. Total organic carbon (TOC) content and $\delta^{13} \mathrm{C}$ data for organic and carbonate carbon in lake 30 samples

\begin{tabular}{lllc}
\hline $\begin{array}{l}\text { Depth } \\
(\mathrm{cm})\end{array}$ & $\begin{array}{l}\text { TOC } \\
(\%)\end{array}$ & $\begin{array}{l}\delta^{13} \mathrm{C} \text { org. } \\
(\% \circ, \mathrm{PDB})\end{array}$ & $\begin{array}{l}\delta^{13} \mathrm{C} \text { carb. } \\
(\% \circ, \mathrm{PDB})\end{array}$ \\
\hline $0-7$ & 4.67 & -16.13 & -2.51 \\
$7-17$ & 2.83 & -14.86 & +1.22 \\
$17-27$ & 2.43 & -16.15 & - \\
$40-50$ & 2.11 & -17.28 & +2.42 \\
$50-60$ & 2.20 & -15.54 & +1.65 \\
$60-68$ & 2.23 & -14.35 & +0.31 \\
$83-93$ & - & -14.76 & +0.14 \\
\hline
\end{tabular}

\section{Discussion}

\subsection{Climatic variations as source of variations in salinity}

Several lines of evidence suggest that sedimentation of the contrasting successive layers in the lakes is controlled by variations of water salinity. Shell-rich layers are considered to form during periods of low to normal salinity. Shell-rich outcrops at the periphery of some lakes 
are considered to be markers of the extension of earlier lakes containing low to normal salinity waters. In contrast, evaporitic deposits, whether in the sediment profile or at the periphery of the lakes, reflect hypersaline conditions. Conditions suitable for the growth of cyanobacterial populations are met in waters with widely varying salinity, from brackish to greater than 300\% (Valencia, 1977).

The main mechanism responsible for recurrent variations of salinity has been attributed by Schoonmaker et al. (1985) to be El Niño-Southern Oscillations (ENSO) events. Visits in July 1983, three and a half months after the end of the 1982-1983 dramatic ENSO event, and in June 1984, approximately 1 year later, allowed Schoonmaker et al. (1985) to observe that: (1) lake surface salinities had decreased in July 1983 to the range of 1.5-55\%o, in contrast to the range of 42-300\%o observed in 1971 by Helfrich et al. (1973), when climatic conditions were not under the control of an ENSO event; (2) many lakes were stratified in 1983, displaying well-defined haloclines and pycnoclines. For example, in lake 10, a somewhat saline upper layer (ca. $40 \%, 28^{\circ} \mathrm{C}$ ) overlaid a hypersaline (up to $250 \%$ ), hot water $\left(60.7^{\circ} \mathrm{C}\right.$ ) layer; and (3) approximately 1 year later (June 1984), surface salinities had recovered to the range of 15$142 \%$, and water column stratification was perceptible in only one pond.

Such observations suggest that the recovery to highly saline conditions takes approximately 1 year, much shorter than the cyclic 6-7-year period which is considered typical for El Niño events (Quinn et al., 1987). The stratification breaks down slowly through evaporation of the upper layer and upward diffusion of solutes in a water body overlying sediment capped by a thick (up to $5 \mathrm{~cm}$ ) cyanobacterial layer. As shown by Schoonmaker et al. (1985), through the existence of conservative ratios between major elements $\mathrm{Na}^{+}, \mathrm{Mg}^{2+}$ and $\mathrm{Cl}^{-}$versus $\mathrm{K}^{+}$, the water in the different ponds is derived from sea water. Following a period of heavy rain, the waters undergo progressive evaporation over a 5-6-year-long period, leading to supersaturation with respect to calcite and to gypsum, and possibly to aragonite and halite, as shown by non-conservative ratios between $\mathrm{Ca}^{2+}, \mathrm{Sr}^{2+}$ and $\mathrm{SO}_{4}{ }^{2-}$ (with respect to $\mathrm{K}^{+}$) (Schoonmaker et al., 1985). Temporary deviations of $\mathrm{Ca}^{2+}$ and $\mathrm{SO}_{4}{ }^{2-}$ concentrations in lake waters collected in July 1983, i.e. shortly after the end of an ENSO event, can be interpreted as resulting from dilution of lake water by the heavy rains and resulting dissolution/precipitation of calcium carbonate and gypsum.

Three months after the end of the 1983 ENSO event and approximately 1 year later (1984), Schoonmaker et al. (1985) measured physico-chemical parameters $(\mathrm{pH}$, alkalinity, dissolved inorganic carbon) consistent with calcium carbonate precipitation in lake waters. In both periods, surface waters were oversaturated with respect to calcite and aragonite, increasing in supersaturation between July 1983 and June 1984. In 1984 the sub-pycnocline water in lake 10 ( Fig. 3) had dropped below calcite saturation, reflecting carbonate precipitation and active photosynthesis.

The sequential precipitation of minerals can therefore be summarized as follows. At the end of an ENSO event and in the period following, water stratification breaks down (ca. 1 year), and the physico-chemical conditions promote calcium carbonate precipitation, both in the lake water and in the underlying microbial mats. During the following 5-6 years, under increasing evaporation, conditions become favorable to calcium carbonate, gypsum and, possibly, halite, precipitation.

As shown by SEM (Fig. 6a-e, g and h), these minerals precipitate within the organic network resulting from the decay of the microbial biomasses and the re-organization of the 
polysaccharidic and glycoproteic constituents of the microbial sheaths ( D and D). This organic network is present throughout the sedimentary column. If gypsum crystals indeed grow through the organic network ( Fig. 6h), the carbonates are likely to precipitate either through biomineralization or organomineralization processes ( Défarge et al., 1996). The term organomineralization refers to a non-biologically supported precipitation in which organic substrates act as templates for carbonate mineral nucleation ( Trichet and Défarge, 1995).

The widespread occurrence of this organic matter throughout the sedimentary column results from continuous growth of significant (up to $5 \mathrm{~cm}$ thick) microbial populations at the sediment surface. Highly organic, more or less dark-colored layers (Fig. 5b-f), correspond to the buried remains of superficial microbial layers. The interruption of the growth of the cyanobacterial benthic populations most likely results from drastic changes in the lake environment, for example heavy rain during ENSO events or heavy storms.

\subsection{Bioproductivity and resulting biogeochemistry of such lagoonal environments}

The presence and abundance of microbially derived organic matter throughout the sediment profile reflects an intense bioproductivity. This active biological production of organic matter is striking in the field and is shown by the centimeters thick (up to $5 \mathrm{~cm}$ ) top living microbial layers, which contrasts with the lower thicknesses of comparable biomasses overlying other biolaminated, stromatolitic sediments (millimeter scale, for example in Solar Lake, Krumbein et al., 1977). Thicknesses similar to those observed in the Christmas Island lakes have been observed in Polynesian reef environments, in kopara sediments ( Défarge et al., 1994). In both cases, high bioproductivity can be related to favorable environmental conditions: high insolation and temperature, due to low latitude, and the lack of carbon limitation in an environment rich in carbonates and largely open to the atmosphere.

This high biological activity is clearly reflected in the isotopic composition of the organic sedimentary carbon. Values reported in Table 2, are comprised between -14.3 and $-17.3 \%$, and are significantly lower than those commonly reported in other microbial mats: -5.7 in Solar Lake and $-10.0 \%$ in Gavish Sabkha ( Schidlowski et al., 1984), -10.1 to $-14.8 \%$ in Laguna Guerrero Negro, Baja California ( Des Marais et al., 1989). They are, however, similar to those measured in Polynesian kopara deposits, -14.6 to $-19.3 \%$ (Défarge and Trichet, unpublished results).

The slightly negative value of $\delta^{13} \mathrm{C}$ in carbonate precipitating in the surface layer of lake 30 (Table 2) suggests a contribution of light $\mathrm{CO}_{2}$ in the carbonate system, either directly from atmospheric $\mathrm{CO}_{2}$ fractionated in conditions of high photosynthetic demand (Lazar and Erez, 1992), or from $\mathrm{CO}_{2}$ derived from organic carbon oxidation.

A striking feature of those lagoonal lakes, when compared to evaporative littoral salinas, is certainly the high relative amount of deposited carbonate versus sulfate + chloride, minerals. This clearly results from two different processes, both acting in carbonate deposition: (1) development of bivalve and gastropod populations during periods of low salinity in the lakes, and (2) intense $\mathrm{Mg}$ calcite precipitation within the organic matter derived from cyanobacteria (organomineralization). Besides climatic conditions favorable to biological growth of either mollusks or cyanobacteria, these two processes result from the lack of limitation of both calcium (abundant in the interstitial solutions of reef rocks and sediments, adding to the calcium provided by periodical sea water inputs) and dissolved carbon species (abundant in 
the interstitial reef solutions and available from the atmosphere). The ratio of deposited carbonate versus sulfate+chloride is therefore higher in these environments than it is in evaporitic salinas, where the solutions submitted to evaporation are essentially replenished by sea water inputs.

\section{Conclusions}

As a whole, the environments represented in the different lakes of Christmas Island provide a general model in which the factors controlling the deposition of (carbonate-evaporiteorganic) laminated sediments are definitely climatic and biologic. Variations in the salinity of lake waters likely reflect short-term (several years) climatic variations related to the ENSO cycle. The importance of biological processes is reflected in both isotopic markers $\left(\delta^{13} \mathrm{C}\right.$ of organic carbon controlled by high photosynthetic activity) and the degree of bacterial and cyanobacterial biomineralization. Physical and chemical diagenetic processes leading, respectively, to sediment aggregation and carbonate organomineralization are controlled by microbially derived sedimentary organic matter. Biomineralization and organomineralization processes involve ionic species (carbonate, $\mathrm{Ca}^{2+}, \mathrm{Mg}^{2+}$ ) whose concentrations are controlled by microbial (essentially bacterial) activities within the different sediment layers, the organic matter present at the surface of the walls of the organic network's chambers acting as templates for mineral nucleation and growth. In any case, these laminated (carbonateevaporite-organic) sediments must reflect the large amounts of organic matter which were present during their formation and which took a key role in their diagenesis.

\section{Acknowledgements}

E. Gibert is kindly thanked for the determination of carbon isotopic values, A.M. Jaunet for help in cryo-SEM observations, D. Panis for X-ray work on lake 30 samples and J.M. Rouchy for providing bibliographical help. We benefited from discussions with S.V. Smith and F.T. Mackenzie. We also thank the reviewers of this paper, Dr C. Schreiber and G. Camoin, as well as C. Taberner and M. Russell for careful reading of the paper.

\section{References}

Bellanca, A. and Neri, R., 1986. Evaporite carbonate cycles of the Messinian, Sicily: stable isotopes, mineralogy, textural features, and environmental implications. J. Sediment. Petrol. 56, pp. 614-621.

Cohen, Y., Ideses, R., 1989. Hypersaline cyanobacterial mats: environmental manipulations for the production of specific carotenoids and specific polysaccharides. In: Miachi, S., Karube, I., Ishida, Y. (Eds.), Current topics in Marine Biotechnology: Proceedings of the First International Marine Biotechnology Conference, Japanese Society for Marine Biotechnology, Tokyo, $437 \mathrm{pp}$.

Decima, A., McKenzie, J.A. and Schreiber, B.C., 1998. The origin of 'evaporative' limestones: an example from the Messinian of Sicily (Italy). J. Sediment. Petrol. 58, pp. 256272.

Défarge, C., Trichet, J., Maurin, A. and Hucher, M., 1994. Kopara in Polynesian atolls: early stages of formation of calcareous stromatolites. Sediment. Geol. 89, pp. 9-23. 
Défarge, C., Trichet, J., Jaunet, A.M., Robert, M., Tribble, J. and Sansone, F.J., 1996. Texture of microbial sediments revealed by cryo-scanning electron microscopy. J. Sediment. Res. 66, pp. 935-947.

Des Marais, D.J., Cohen, Y., Nguyen, H., Cheatham, M., Cheatham, T. and Munoz, E., 1989. Carbon isotopic trends in the hypersaline ponds and microbial mats at Guerrero Negro, Baja California Sur, Mexico: implications for Precambrian stromatolites. In: Cohen, Y. and Rosenberg, E., Editors, 1989. Microbial Mats: Physiological Ecology of Benthic Microbial Communities, American Society for Microbiology, Washington, DC, pp. 97-113.

Goldsmith, J.R. and Graf, D.L., 1958. Relation between lattice constants and composition of the $\mathrm{Ca}-\mathrm{Mg}$ carbonates. Am. Miner. 43, pp. 84-101.

Helfrich, P. et al., 1973. The feasibility of brine shrimp production on Christmas Island. Sea Grant Technical Report UNIHI-SEAGRANT-TR-73-02, 173 pp.

Krumbein, W.E., Cohen, Y. and Shilo, M., 1977. Solar Lake (Sinai). 4. Stromatolitic cyanobacterial mats. Limnol. Oceanogr. 22, pp. 635-656.

Lazar, B. and Erez, J., 1992. Carbon geochemistry of marine-derived brines: I. $\delta^{13} \mathrm{C}$ depletions due to intense photosynthesis. Geochim. Cosmochim. Acta 56, pp. 335-345.

Maiklem, W.R., 1971. Evaporative drawdown - a mechanism for water-level lowering and diagenesis in the Elk Point Basin. Bull. Can. Pet. Geol. 19, pp. 487-503.

McKenzie, J.A., 1985. Stable isotope mapping in Messinian evaporative carbonates of Central Sicily. Geology 13, pp. 851-854.

Ortí, F., Pueyo, J.J., Geisler, D. and Dulau, N., 1984. Evaporitic sedimentation in the coastal salinas of Santa Pola (Alicante, Spain). Rev. Inst. Inv Geol. 38-39, pp. 169-220.

Quinn, W.H., Neal, V.T. and Antunez de Mayolo, S.E., 1987. El Niño occurrences over the past four and a half centuries. J. Geophys. Res. 92 C13, pp. 14,449-14,461.

Rouchy, J.M., Taberner, C., Blanc-Valleron, M.M., Sprovieri, R., Russell, M., Pierre, C., Di Stafano, E., Pueyo, J.J., Caruso, A., Dinarès-Turell, J., Gomis-Coll, E., Wolff, G., Cespuglio, G., Ditchfield, P., Pestrea, S., Combourieu-Nebout, N., Santisteban, C. and Grimalt, J.O., 1998. Sedimentary and diagenetic markers of the restriction in a marine basin: the Lorca basin (SE Spain) during the Messinian. Sediment. Geol. 121, pp. 23-55.

Schidlowski, M., Matsizkeit, U. and Krumbein, W.E., 1984. Superheavy organic carbon from hypersaline microbial mats. Naturwissenschaften 71, pp. 303-308.

Schmalz, R.F., 1969. Deep-water evaporite deposition: a genetic model. Am. Assoc. Pet. Geol. Bull. 53, pp. 798-823.

Schoonmaker, J., Tribble, G.W., Smith, S.V., Mackenzie, F.T., 1985. Geochemistry of saline ponds, Kiritimati (Republic of Kiribati). In: Gabrie, C., Toffart, J.L., Salvat, B. (Eds.), Fifth International Coral Reef Congress, Papeete, Tahiti, vol. 3, pp. 439-444. 
Trichet, J. and Défarge, C., 1995. Non-biologically supported organomineralization. Bull. Inst. Oceanogr., Monaco (special issue) 14 2, pp. 203-236.

Trichet, J., Défarge, C., 1999. Sedimentary organic matter derived from cyanobacteria: composition, structure and propeties of kopara deposits. Bull. Inst. Oceanogr., Monaco (special issue) 19, 203-208.

Valencia, M., 1977. Christmas Island (Pacific Ocean): reconnaissance geologic observations. Atoll Res. Bull. 197, pp. 1-14. 